\title{
PENGUATAN FUNGSI LEGISLATIF DAN EVALUASI KINERJA BIDANG PENGANGGARAN (Studi di DPRD Kota Batu)
}

\author{
Asfi Manzilati \\ Fakultas Ekonomi \& Bisnis Universitas Brawijaya \\ Maftuch \\ M. Fadli \\ Fakultas Hukum Universitas Brawijaya
}

\begin{abstract}
Changes in performance-based budgeting system (performance budgeting) that promotes community participation, provide an important role in Parliament as representatives of the people drafting process, in accordance with Law no. 17 of 2003 on State Finance. Implementation of the people's rights in the budget can be realized in community involvement in participatory planningand budgeting process. This study aims to (1) to know legislators understanding in Batu City and its implementation to the function of budgeting, (2) to evaluate the performance of budgeting in Batu City. Using a qualitative approach, results of this study are: (1) Legislators' understanding in Batu City tend to function as a means of budgeting "bargain" with local government, and lack of touch on the substance to the public welfare, (2)Parliament has used "Alat Kelengkapan Dewan" associated with the budgeting of the "Badan Anggaran", frequently board members's budget is more than the amount of budget approved by the municipal government of Batu City. But this condition still happened because the government afraid of the revenue and expenditure budget (APBD) not approved by parliament.
\end{abstract}

Keywords: budget, parliament batu, legislative functions

\section{A. LATAR BELAKANG}

Salah satu dampak dari orde reformasi yang menjadi perhatian utama sampai saat ini adalah menyangkut isu kebijakan otonomi daerah. Pemerintah melalui kebijakan "Desentralisasi" (politik, hukum, dan fiskal) dengan dikeluarkannya Undang Undang No. 22 Tahun 1999 tentang Pemerintah Daerah dan telah dicabut dengan Undang Undang No. 32 tahun 2004. Lahirnya kedua Undang undang tersebut telah membawa perubahan signifikan dalam beberapa aspek seperti politik, pembentukan daerah dan kawasan khusus, pengelolaan keuangan daerah, pemanfaatan sumber sumber daya daerah untuk kepentingan masyarakat lokal terhadap hubungan pemerintah pusat dan daerah. 
Proses pelaksanaan otonomi daerah yang sudah berjalan sejak Januari 2001 dalam kenyataannya belum berjalan sesuai dengan apa yang diharapkan. Adanya interpretasi yang berbeda antara pusat dan daerah merupakan salah satu faktor yang menyebabkan pelaksanaan aturan pemerintahan tidak singkron. Selain juga adanya tumpang tindih antara peraturan perundangan yang ada di daerah dengan pusat, hal tersebut bisa berupa peraturan perundangan yang sama ataupun peraturan perundangan yang berlawanan antara aturan yang berada di bawah dengan aturan yang ada diatasnya (secara hierarki). Pembentukan undang-undang merupakan salah satu unsur penting di samping unsur-unsur lainnya dalam rangka pembangunan sistem hukum nasional.

Perubahan system penganggaran berbasis kinerja (performance budgeting) yang mengutamakan partisipasi masyarakat, memberikan peran penting DPRD sebagai wakil rakyat dalam proses penyusunannya, sesuai dengan UU no. 17 Tahun 2003 tentang Keuangan Negara. Implementasi hak rakyat dalam APBD dapat diwujudkan dalam keterlibatan masyarakat secara partisipatif dalam proses perencanaan dan penganggaran. Masyarakat sering tidak puas dengan kinerja APBD dan keluhan masyarakat sering terjadi terhadap ketimpangan antara pengeluaran belanja pemerintah dan alokasi anggaran untuk publik. Persoalan perencanaan penganggaran sangat penting untuk dicermati karena dapat dijadikan penilaian terhadap pemerintah mengenai keberpihakan terhadap masyarakat.

Fungsi pengawasan menjadi titik krusial penciptaan pemerintahan yang baik (good governance), karena akan mempersempit ruang bagi terjadinya perbuatan pemerintah yang tercela. Perbuatan pemerintah yang tercela frekuensinya lebih banyak terjadi dalam pemerintahan yang bebas, sedangkan pemerintahan yang bebas identik dengan penerapan otonomi daerah, dimana pemberian kewenangan dan keleluasaan diberikan kepada daerah untuk mengelola dan memanfaatkan sumber daya daerah secara optimal bagi kesejahteraan masyarakat. Di era desentralisasi dan demokrasi seperti ini memberi ruang dan peran DPRD yang semakin besar untuk menjadi mitra pemerintah dalam proses penyelenggaraan pemerintahan yang demokratis, bersih dan berwibawa.

Pada sisi yang lain, kualitas pengawasan (dalam penganggaran) sangat bergantung pada pemahaman dan kinerja anggota DPRD. Terlebih lagi telah terjadi perubahan sistem penganggaran berbasis kinerja (performance budgeting) yang mengutamakan partisipasi masyarakat. Tujuan dari penelitian ini adalah 1). mengetahui pemahaman anggota DPRD Kota Batu dan penerapannya terhadap fungsi penganggaran; dan 2). mengevaluasi kinerja bidang penganggaran DPRD Kota Batu.

\section{B. KAJIAN TEORITIS}

\section{Dewan Perwakilan Rakyat Daerah}

Secara umum DPRD mempunyai 3 (tiga) fungsi dasar yaitu: fungsi perwakilan, fungsi pembuatan kebijakan (legislasi), dan fungsi pengawasan. Dari ketiga fungsi tersebut, fungsi legislasi dinilai oleh banyak kalangan sebagai fungsi yang paling sedikit (kurang) mendapat 
perhatian dari para anggota dewan. Untuk dapat melaksanakan fungsi ini dengan baik memang sangat diperlukan pemahaman yang mendalam terhadap persoalan yang dihadapi, wawasan yang luas, dan tentu saja kemampuan teknis yang memadai. Selain itu tahapan-tahapan yang harus dilalui untuk dapat menghasilkan suatu produk legislasi yang berkualitas, memerlukan proses yang tidak gampang (Wismar E, 2004)

Kedudukan DPRD adalah: pertama DPRD merupakan Lembaga Perwakilan Rakyat Daerah yang berkedudukan sebagai Lembaga Pemerintahan Daerah. Sedang yang kedua adalah DPRD sebagai unsur Lembaga Pemerintahan Daerah memiliki tanggungjawab yang sama dengan Pemerintah Daerah dalam membentuk Peraturan Daerah untuk kesejahteraan rakyat. Fungsi DPRD adalah: 1. Legislasi : Diwujudkan dalam mem-bentuk Peraturan Daerah bersama Kepala Daerah. 2. Anggaran : Diwujudkan dalam menyusun dan menetapkan APBD bersama Pemerintah Daerah. 3. Pengawasan : Diwujudkan dalam bentuk pengawasan ter-hadap pelaksanaan. Undang-undang, Peraturan Daerah, Keputusan Kepala Daerah dan kebijakan yang ditetapkan oleh Pemerintah Daerah

\section{Good Governance}

Kata governance, diterjemahkan ke dalam bahasa Indonesia menjadi "tata pemerintahan". Dari pemahaman tersebut diperoleh gambaran bahwa governance adalah cara, bagaimana kekuasaan Negara digunakan untuk mengelola sumber daya ekonomi dan social guna pembangunan masyarakat. Governance juga bisa diartikan sebagai pelaksanaan otoritas politik ekonomi, administrasi untuk mengelola masalah nasional pada semua tingkatan. Persyaratan minimal untuk mencapai good governance adalah transparansi, akuntabilitas, partisipasi, penegak hokum, efektifitas, dan keadilan.

Keterlibatan masyarakat dalam setiap jenjang proses pengambilan keputusan, terutama menyangkut masyarakat, misalnya dalam pengelolaan sumberdaya alam, akan menjadi semacam aktifitas pendukung pengelolaan (co-management) yang terdiri atas suara rakyat dan tindakantindakan responsive pemerintah. Governance di dukung oleh tiga kaki yakni politik, ekonomi dan administrasi. Disamping itu governance atau tata pemerintahan memiliki tiga domain yaitu: 1. Negara atau pemerintahan (state)

2. Sektor swasta atau dunia usaha (private sektor), dan

3. Dan masyarakat (society)

Ketiga domain diatas berada dalam kehidupan berbangsa, bernegara, dan bermasyarakat. Aktor pemerintah berperan dalam pembuatan kebijakan, pengendalian dan pengawasan. Sektor swasta lebih banyak sebagai penggerak ekonomi. Sedangkan masyarakat adalah sebagai obyek sekaligus subyek dari sektor pemerintah maupun swasta. Karena didalam masyarakat terjadi interaksi politik, ekonomi, dan sosial budaya. Governance yang dijalankan oleh ketiga domain tersebut tidak sekadar jalan melainkan harus masuk kategori baik (good). Perpaduan antara kata good dan governance menimbulkan kosakata baru yaitu good governance, yang dewasa ini menjadi sangat popular.

Sejak dicetuskannya tentang tata pemerintahan yang baik, atau yang sering dikenal dengan Good Governance pada akhir tahun 90an dan dinyatakan sebagai komitment dalam 
pelaksanaan pemerintahan pada awal tahun 2000, penganggaran daerah bukan lagi monopoli bagi pelaksana pemerintah,yaitu pemerintah dan DPRD. Dalam era baru pengelolaan pemerintahan. pemerintah adalah salah satu pilarnya dari 3 pilar tata pemerintahan. Dengan demikian pemerintah adalah salah satu bagian dari unsur tata pemerintahan. Sedangkan 2 pilar yang lain adalah sektor swasta (private sector) dan masyarakat sipil (civil society organization) (Pietra W).

Peraturan Daerah (PERDA) adalah instrument aturan yang secara sah diberikan kepada pemerintah daerah dalam menyelenggarakan pemerintahan di daerah. Sejak Tahun 1945 hingga sekarang ini, telah berlaku beberapa undang-undang yang menjadi dasar hukum penyelenggaraan pemerintahan daerah dengan menetapkan Perda sebagai salah satu instrumen yuridisnya. (Himawan E B). Kedudukan dan fungsi perda berbeda antara yang satu dengan lainnya sejalan dengan sistem ketatanegaraan yang termuat dalam UUD/ Konstitusi dan UU Pemerintahan Daerahnya. Perbedaan tersebut juga terjadi pada penataan materi muatan yang disebabkan karena luas sempitnya urusan yang ada pada pemerintah daerah.

Demikian juga terhadap mekanisme pembentukan dan pengawasan terhadap pembentukan dan pelaksanaan perda pun mengalami perubahan seiring dengan perubahan pola hubungan antara pemerintah pusat dengan pemerintah daerah. Setiap perancang perda, terlebih dahulu harus mempelajari dan menguasai aturan hukum positip tentang UU Pemerintahan Daerah, UU tentang Perundang-undangan, Peraturan pelaksanaan yang secara khusus mengatur tentang perda. Untuk merancang sebuah perda, perancang pada dasarnya harus menyiapkan diri secara baik dan mengusai hal-hal sebagai berikut :

a. Analisa data tentang persoalan sosial yang akan diatur.

b. Kemampuan teknis perundang-undangan.

c. Pengetahuan teoritis tentang pembentukan aturan.

Hukum perundang-undangan baik secara umum maupun khusus tentang perda

\section{Peraturan Daerah (PERDA)}

Peraturan Daerah (PERDA) adalah instrument aturan yang secara sah diberikan kepada pemerintah daerah dalam menyelenggarakan pemerintahan di daerah. Sejak Tahun 1945 hingga sekarang ini, telah berlaku beberapa undang-undang yang menjadi dasar hukum penyelenggaraan pemerintahan daerah dengan menetapkan Perda sebagai salah satu instrumen yuridisnya. (Himawan E B).

Kedudukan dan fungsi perda berbeda antara yang satu dengan lainnya sejalan dengan sistem ketatanegaraan yang termuat dalam UUD/ Konstitusi dan UU Pemerintahan Daerahnya. Perbedaan tersebut juga terjadi pada penataan materi muatan yang disebabkan karena luas sempitnya urusan yang ada pada pemerintah daerah.

Demikian juga terhadap mekanisme pembentukan dan pengawasan terhadap pembentukan dan pelaksanaan perda pun mengalami perubahan seiring dengan perubahan pola hubungan antara pemerintah pusat dengan pemerintah daerah. Setiap perancang perda, terlebih dahulu harus mempelajari dan menguasai aturan hukum positip tentang UU Pemerintahan Daerah, UU tentang Perundang-undangan, Peraturan pelaksanaan yang secara khusus mengatur tentang perda. 
Untuk merancang sebuah perda, perancang pada dasarnya harus menyiapkan diri secara baik dan mengusai hal-hal sebagai berikut:

a. Analisa data tentang persoalan sosial yang akan diatur.

b. Kemampuan teknis perundang-undangan.

c. Pengetahuan teoritis tentang pembentukan aturan.

d. Hukum perundang-undangan baik secara umum maupun khusus tentang perda.

\section{Pengertian dan Fungsi Anggaran Daerah}

APBD (Anggaran Pendapatan dan Belanja Daerah) merupakan pencerminan pelaksanaan pembangunan daerah dalam pengembangan akuntabilitas dan kapabilitas pemerintah. Masyarakat merupakan penyumbang utama sumber penerimaan dalam APBD melalui pajak dan retribusi maka sudah sepantasnya masyarakat dilibatkan dalam proses penyusunannya. Implementasi hak rakyat dalam APBD dapat diwujudkan dalam keterlibatan masyarakat secara partisipatif dalam proses perencanaan dan penganggaran. Masyarakat sering tidak puas dengan kinerja APBD dan keluhan ketimpangan yang terjadi antara pengeluaran pemerintah dan publik menjadi sorotan. Dengan keluarnya UU No. 25 Tahun 2004 Tentang Sistem Perencanaan Pembangunan Nasional dan UU No. 17 Tahun 2003 Tentang Keuangan Negara memberi kesempatan bagi masyarakat untuk ikut terlibat dalam proses perencanaan dan penganggaran.

Persoalan dalam perencanaan dan penganggaran ini sangat penting untuk dicermati karena dapat dijadikan penilaian terhadap pemerintah mengenai keberpihakan terhadap masyarakat lemah dan dapat mempengaruhi kebijakan yang nantinya akan diterapkan pada suatu daerah baik pada bidang perencanaan dan penganggaran maupun dalam bidang partisipasi masyarakatnya. Persoalan partisipasi masyarakat dalam perencanaan dan penganggaran melibatkan berbagai stakeholder baik dari DPRD, Pemerintah Daerah, Masyarakat,maupun organisasi non-pemerintah. Masing-masing pelaku mempunyai peranan penting yang saling terkait satu dengan yang lain. (Wahyu D W, 2007).

Perubahan penganggaran terjadi sejak tahun 2002 setelah dikenalkannya sistem anggaran kinerja (performance budgeting). Pendekatan kinerja tersebut mengutamakan partisipasi masyarakat, yang juga melibatkan stakeholder lain termasuk Pemerintah dan DPRD. Pentingnya keterikatan antar elemen pembangunan dalam membangun sistem yang sinergis dijelaskan berturut-turut dengan dikeluarkannya UU No. 17 Tahun 2003 tentang Keuangan Negara, UU No. 32 Tahun 2004 Tentang Pemerintah Daerah dan UU No 25 tahun 2004 tentang Sistem Perencanaan Pembangunan Nasional (SPPN). Khusus pada UU No. 25 Tahun 2004 dijelaskan bahwa proses perencanaan dan penganggaran diselenggarakan secara sinergis. Tahapan perencanaan disatukan dengan tahapan penganggaran hingga menghasilkan APBD.

Proses perencanaan yang ada dimulai dari penggalian gagasan masyarakat untuk mengetahui permasalahan yang terjadi di daerahnya masing-masing. Sebelum keluarnya perundangan yang tersebut diatas, peran masyarakat tidak begitu diperhitungkan. Pergeseran ini terjadi karena masyarakat di tiap daerah dituntut dan merasa perlu berperan dalam perkembangan daerahnya. Hal ini sesuai dengan amanat otonomi daerah yang menginginkan masyarakat untuk terlibat aktif memberikan masukan penyusunan APBD. 
Adanya wacana untuk melibatkan masyarakat bukan hanya pada tataran perencanaan tetapi juga pada penganggaran merupakan suatu hal yang positif dalam proses transparansi yang coba dibangun oleh Pemerintah. Proses partisipasi masyarakat dalam perencanaan telah dicoba direspon oleh berbagai daerah. Dalam proses perencanaan sesuai UU No. 25 Tahun 2004 proses pelibatan masyarakat tersebut dikenal dengan nama Musyawarah Perencanaan Pembangunan (Musrenbang). Lebih jauh lagi, Musrenbang ini merupakan forum antar pelaku dalam menyusun perencanaan pembangunan. Istilah nama tersebut berkembang di tiap daerah disesuaikan dengan kebijakan yang diterapkan.

Di era reformasi, pemerintah telah melakukan perubahan penting dan mendasar, dengan maksud untuk memperbaiki berbagai kekurangan yang ada serta upaya untuk mengakomodasi berbagai tuntutan dan aspirasi yang berkembang di daerah dan masyarakat. Pemberlakuan Undang-Undang Nomor 32 Tahun 2004 tentang Pemerintah Daerah dan Undang-Undang Nomor 33 Tahun 2004 tentang Perimbangan Keuangan Antara Pusat dan Daerah, membawa perubahan fundamental dalam hubungan tata pemerintah dan hubungan keuangan serta dalam hal pengelolaan anggaran daerah. Otonomi daerah memiliki implikasi terhadap penyelenggaraan pemerintahan yang harus berorientasi pada peningkatan kesejahteraan masyarakat dengan selalu memperhatikan kepentingan dan aspirasi yang tumbuh dalam masyarakat.

Banyak aspek yang muncul dari adanya reformasi keuangan daerah. Namun, yang paling umum menjadi sorotan bagi pengelola keuangan daerah adalah adanya aspek perubahan mendasar dalam pengelolaan anggaran daerah (APBD) yaitu perubahan dari traditional budget ke performance budget. Perubahan paradigma anggaran daerah dilakukan untuk menghasilkan anggaran daerah yang benar-benar mencerminkan kepentingan dan pengharapan masyarakat daerah setempat terhadap pengelolaan keuangan daerah secara ekonomis, efisien dan efektif.

Anggaran Pendapatan dan Belanja Daerah (APBD) disusun berdasarkan pendekatan kinerja, yaitu sistem penyusunan dan pengelolaan anggaran daerah yang berorientasi pada pencapaian hasil kinerja. Kinerja tersebut harus mencerminkan efisiensi dan efektivitas pelayanan publik, yang berarti harus berorientasi pada kepentingan publik (Rahayu dkk, 2007). Oleh karena itu, anggaran dianggap sebagai pencerminan program kerja (Bastian, 2006b: 53). Untuk memenuhi tujuan akuntabilitas dan keterbukaan dalam melaksanakan pelayanan kepada masyarakat, pos-pos anggaran harus dikelompokkan ke dalam kegiatan-kegiatan (sebagai cost object) dengan menetapkan berbagai standar biaya, pelayanan minimal dan kinerja (Muhammad D, 2008).

\section{Regulasi yang Mengatur Partisipasi Masyarakat dalam Proses Perencanaan dan Penganggaran}

Pemerintah telah menerbitkan serangkaian peraturan perundangan untuk mendorong partisipasi masyarakat dalamproses resmi perencanaan dan penganggaran daerah. Peraturanperaturan tersebut meliputi:

Undang-Undang No. 32/2004 tentang Pemerintahan Daerah; meletakkan partisipasi masyarakat sebagai elemen penting untuk mencapai tujuan kesejahteraan masyarakat; menciptakan rasa memiliki masyarakat dalam pengelolaan pemerintahan daerah; menjamin terdapatnya 
transparansi, akuntabililitas dan kepentingan umum; perumusan program dan pelayanan umum yang memenuhi aspirasi masyarakat.

Undang-Undang 25/2004 tentang Sistem Perencanaan Pembangunan Nasional; melembagakan Musrenbang di semua peringkat pemerintahan dan perencanaan jangka panjang, jangka menengah dan tahunan.Menekankan tentang perlunya sinkronisasi lima pendekatan perencanaan yaitu pendekatan politik, partisipatif, teknokratis, 'bottom-up' dan 'top down' dalam perencanaan pembangunan daerah.

Surat Edaran Bersama Menteri Negara Perencanaan Pembangunan Nasional dan Menteri Dalam Negeri (Mendagri) Tahun 2006 tentang Petunjuk Teknis Penyelenggaraan Musrenbang; mengatur titik masuk (entry point) partisipasi masyarakat dalam proses perencanaan dan penganggaran daerah. Surat edaran bersama ini juga mempedomani tata cara, capaian, prosedur, proses, dan mekanisme penyelenggaraan Musrenbang dan forum multistakeholder SKPD.

Secara keseluruhan dapat dikatakan bahwa Pemerintah Indonesia telah menciptakan kerangka bagi Musrenbang untuk dapat mensinkronisasikan perencanaan 'bottom-up' dengan 'top down' dan merekonsiliasikan berbagai kepentingan dan kebutuhan pemerintah daerah dan non pemerintah daerah dalam perencanaan pembangunan daerah.

\section{METODE PENELITIAN DAN ANALISIS DATA}

Pentingnya pencapaian kinerja DPRD merupakan persoalan yang belum banyak diteliti Oleh karena itu penelitian ini dimaksudkan lebih sebagai penelitian eksploratif yang bertujuan untuk meninjau dari aspek profesionalisme dan kelembagaan dan eksplorasi masalah-masalah yang terjadi dalam tubuh kelembagaan sehingga dapat dirumuskan tindak lanjut untuk peningkatan kinerja DPRD. Penelitian ini menggunakan metode kualitatif. Paradigma kualitatif menekankan pada pemahaman mengenai masalah-masalah dalam kehidupan sosial berdasarkan kondisi realitas atau natural setting yang kompleks dan rinci (Sugiyono, 2007:23).

Pilihan pendekatan kualitatif ini sejalan dengan apa yang dikemukakan oleh Moleong (2004: 8)sebagai berikut: "Penelitian kualitatif berakar pada latar alamiah sebagai keutuhan, mengandalkan manusia sebagai alat penelitian, memanfaatkan metode kualitatif, mengarahkan sasaran penelitian kepada usaha menemukan teori dari dasar, bersifat deskriptif, lebih mementingkan proses daripada hasil, membatasi studi dengan fokus, memiliki seperangkat kriteria untuk memeriksa keabsahan data, rancangan penelitian bersifat sementara dan hasil penelitiannya disepakati oleh kedua belah pihak: peneliti dan subyek penelitian".

\section{Unit Analisis dan Penentuan Informan}

Unit analisis dalam penelitian ini adalah kinerja DPRD yang ditinjau dari aspek profesionalisme dan kelembagaan. Profesionalisme dan kelembagaan yang dimaksud adalah kinerja DPRD yang mendukung terciptanya good governance. Terciptanya good governance dalam hal ini harus tercukupinya transparansi, akuntabilitas, partisipasi, penegakan hukum, efektifitas, dan keadilan. Pada gilirannya, hasil penelitian ini diharapkan dapat menjadi dasar untuk usaha peningkatan kinerja DPRD itu sendiri. 
Dengan penentuan unit analisis ini diharapkan pengumpulan data dapat dipusatkan di sekitarnya. Data yang dikumpulkan adalah apa yang terjadi dalam kegiatannya, apa yang mempengaruhi, bagaimana sikapnya, dan semacamnya. Sebagai subjek penelitian, dari para anggota DPRD kota Batu (dan individu lain yang terkait) disaring sesuai dengan kebutuhan penelitian.

Dalam penelitian ini, informasi (data) akan digali melalui 2 sumber, yaitu: pertama, anggota DPRD sebagai individu yang memiliki pengalaman pribadi terkait dengan permasalahan penelitian (key informan). Kedua, individu lain yang terkait (pemerintah dan masyarakat) atau ahli (pakar) yang sesuai permasalahan yang diteliti. Memperoleh informasi penelitian melalui key informan digunakan apabila peneliti sudah memahami informasi awal tentang obyek penelitian maupun informasi penelitian, sehingga ia membutuhkan key person untuk memulai melakukan wawancara atau observasi (Bungin, 2007: 77). Penentuan informan ini dilakukan secara sengaja (purposive) dengan pertimbangan sebagai berikut: (1) Orang yang bersangkutan memiliki pengalaman pribadi sesuai dengan permasalahan yang diteliti, dalam hal ini adalah para pengusaha mikro; (2) Orang tersebut sehat jasmani dan rohani; (3) Orang yang bersangkutan memiliki pengetahuan yang luas mengenai permasalahan yang diteliti.

\section{Jenis dan Sumber Data}

Data merupakan keterangan dari sesuatu hal, dapat berupa sesuatu yang diketahui atau yang dianggap dan anggapan (Hasan, 2002). Kriteria data dalam penelitian kualitatif adalah data yang pasti. Data yang pasti adalah data yang sebenarnya terjadi sebagaimana adanya, bukan data yang sekedar yang terlihat, terucap, tetapi data yang mengandung makna dibalik yang terlihat dan terucap tersebut (Sugiyono, 2007:2).

Adapun penelitian ini menggunakan jenis data primer dan data sekunder. Data primer sendiri adalah data yang diperoleh langsung dari objek penelitian. Data primer dalam penelitian ini diperoleh dari anggota DPRD. Sedangkan data sekunder dalam penelitian ini diperoleh dari berbagai sumber, antara lain: publikasi ilmiah, literatur, data statistik, sumber elektronik, dan lain-lain.

\section{Teknik Pengumpulan Data}

Teknik pengumpulan data yang digunakan dalam penelitian ini meliputi:

\section{Wawancara Mendalam Semi terstruktur}

Wawancara mendalam dianggap peneliti sebagai sarana yang tepat untuk menjembatani keadaan obyek penelitian dan hasil yang ingin di dapatkan oleh peneliti. Wawancara mendalam dimaksudkan untuk memperoleh keterangan, pendirian, pendapat secara lisan dari seseorang (responden) dengan berbicara langsung dengan orang tersebut. Dengan metode semiterstruktur, dalam pelaksanaanya wawancara bersifat lebih bebas bila dibandingkan dengan wawancara terstruktur. Seperti yang diungkapkan oleh Sugiyono (2007:73) bahwa tujuan dari wawancara semiterstruktur adalah untuk menemukan permasalahan secara lebih terbuka, dimana pihak yang diajak wawancara selain memberikan informasi juga diminta pendapat serta ide-ide mengenai permasalahan yang ditanyakan. 


\section{Observasi Partisipatif}

Observasi partisipatif dilakukan melalui pengamatan dengan melibatkan peneliti. Dalam observasi partisipatif, peneliti terlibat dengan keadaan sehari-hari orang yang sedang diamati atau yang digunakan sebagai sumber data penelitian. Sambil melakukan penelitian, peneliti ikut melakukan apa yang dikerjakan oleh sumber data dan ikut merasakan suka dukanya (Sugiyono, 2007: 64).

\section{Dokumentasi}

Hasil penelitian dari observasi atau wawancara, akan lebih kredibel/dapat dipercaya kalau didukung oleh dokumentasi dari obyek penelitian. Dokumentasi juga dapat berupa data-data yang dimiliki oleh dinas dan instansi yang terkait dengan subyek penelitian. Dalam penelitian ini, contoh dokumentasi misalnya dokumen-dokumen penting yang dimiliki dinas perindustrian yang mendukung dalam proses penelitian.

\section{Teknik Keabsahan Data}

Untuk memperoleh temuan yang dapat dipertanggungjawabkan, maka yang dapat dilakukan adalah pengujian dengan trianggulasi. Trianggulasi dalam pengujian kredibilitas ini diartikan sebagai pengecekan data dari berbagai sumber dengan berbagai metode.

1. Trianggulasi Sumber

Trianggulasi sumber dilakukan dengan cara mengecek data yang diperoleh melalui beberapa sumber.

2. Trianggulasi Metode

Trianggulasi metode dilakukan dengan cara mengecek data kepada sumber yang sama dengan metode yang berbeda

\section{Teknik Analisis Data}

Analisis data adalah proses mencari dan menyusun secara sistematis data yang diperoleh dari hasil wawancara, catatan lapangan dan bahan-bahan lain, sehingga dapat mudah dipahami dan temuannya dapat diinformasikan kepada orang lain. Analisiis data dilakukan dengan mengorganisasikan data, menjabarkannya ke dalam unit-unit, melakukan sintesa, menyusun ke dalam pola, memilih mana yang penting dan yang akan dipelajari dan membuat kesimpulan yang dapat diceritakan kepada orang lain (Sugiyono, 2007:88). Dalam penelitian ini analisis data yang digunakan dapat ditunjukkan dalam gambar berikut: 


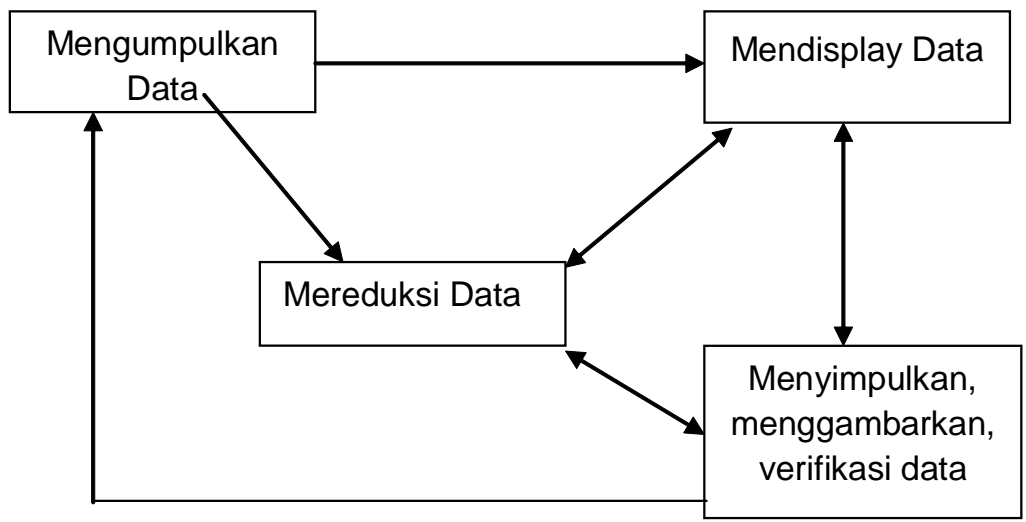

Gambar 1. Komponen dalam Analisis Data

Sumber: Sugiyono (2007:183)

\section{HASIL DAN PEMBAHASAN}

\section{Gambaran Umum Dewan Perwakilan Rakyat Daerah (DPRD) Kota Batu}

Sesuai Peraturan DPRD Kota Batu Nomor 01 Tahun 2010 tentang Tata Tertib Dewan Perwakilan Rakyat Daerah Kota Batu, DPRD merupakan Lembaga Perwakilan Rakyat Daerah yang berkedudukan sebagai unsur penyelenggara Pemerintahan Daerah. DPRD sebagai unsur penyelenggara Pemerintah Daerah memiliki tanggung jawab yang sama dengan Pemerintah Derah dalam membentuk Peraturan Daerah untuk kesejahteraan rakyat.

Peraturan DPRD Kota Batu Nomor 01 Tahun 2010 pasal 2, menyatakan bahwa DPRD Kota Batu terdiri dari Anggota Partai Politik peserta Pemilihan Umum yang terpilih berdasarkan hasil Pemilihan Umum Legislatif Tahun 2009. Adapun partai-partai pemenang dan terpilih sebagai anggota DPRD Kota Batu Periode 2009-2014 adalah Partai Demokrasi Indonesia Perjuangan (PDIP), Partai Golongan Karya (Golkar), Partai Hati Nurani Rakyat (Hanura), Partai Amanat Nasional (PAN), Partai Demokrat (PD), Partai Perjuangan Indonesia Baru (PPIB), Partai Patriot (PP), Partai Nasional Indonesia Marheinisme (PNIM), Partai Keadilan Nahdatul Ulama (PKNU), Partai Karya Peduli Bangsa (PKPB), Partai Keadilan Sejahtera (PKS), dan Partai Barisan Nasional (Barnas).

Sementara itu pada Peraturan DPRD Kota Batu Nomor 01 Tahun 2010 Pasal 5, dijelaskan tugas dan wewenang DPRD Kota Batu adalah sebagai berikut:

a. Membentuk peraturan daerah bersama Kepala Daerah;

b. Membahas dan memberikan persetujuan Rancangan Peraturan Daerah mengenai APBD yang diajukan oleh Kepala Daerah;

c. Melaksanakan pengawasan terhadap pelaksanaan peraturan daerah dan APBD;

d. Mengusulkan pengangkatan dan/atau pemberhentian kepala daerah dan/atau wakil kepala daerah kepada Menteri Dalam Negeri melalui Gubernur untuk mendapatkan pengesahan pengangkatan dan/atau pemberhentian; 
e. Memilih wakil kepala daerah dalam hal terjadi kekosongan jabatan wakil kepala daerah;

f. Memberikan pendapat dan pertimbangan kepada Pemerintah Daerah terhadap terhadap rencana perjanjian internasional di daerah;

g. Memberikan persetujuan terhadap rencana kerja sama internasional yang dilakukan oleh Pemerintah Daerah;

h. Meminta Laporan Keterangan Pertanggungjawaban Kepala Daerah dalam penyelenggaraan pemerintah daerah;

i. Memberikan persetujuan terhadap rencana kerja sama dengan daerah lain atau dengan pihak ketiga yang membebani masyarakat dan daerah;

j. Mengupayakan terlaksananya kewajiban daerah sesuai dengan ketentuan peraturan perundang-undangan;

k. Melaksanakan tugas dan wewenang lain yang diatur dalam ketentuan peraturan perundangundangan.

Dalam menjalankan tugas dan wewenangnya, DPRD mempunyai hak sesuai Peraturan DPRD Kota Batu Nomor 01 Tahun 2010 Pasal 10, yaitu:

a. Interpelasi

Hak untuk meminta keterangan kepada Kepala Daerah mengenai kebijakan Pemerintah Daerah yang penting dan strategis serta berdampak luas pada kehidupan bermasyarakat dan bernegara.

b. Angket

Hak DPRD untuk melakukan penyelidikan terhadap kebijakan Pemerintah Daerah yang penting dan strategis serta berdampak luas pada kehidupan masyarakat, daerah dan negara yang diduga bertentangan dengan ketentuan peraturan perundang-undangan.

c. Menyatakan pendapat

Hak DPRD untuk menyatakan pendapat terhadap kebijakan Kepala Dearah atau mengenai kejadian luar biasa yang terjadi di daerah disertai dengan rekomendasi penyelesaiannya atau sebagai tindak lanjut pelaksanaan hak interpelasi dan hak angket.

Selanjutnya mengenai hak dan kewajiban anggota DPRD diatur dalam Peraturan DPRD Kota Batu Nomor 01 Tahun 2010 Pasal 19 dan 30. Dimana menurut pasal 19 anggota DPRD mempunyai hak, diantaranya:

a. Mengajukan rancangan peraturan daerah;

b. Mengajukan pertanyaan;

c. Menyampaikan usul dan pendapat;

d. Memilih dan dipilih;

e. Membela diri;

f. Imunitas;

g. Mengikuti orientasi dan pendalaman tugas;

h. Protokoler; dan

i. Keuangan dan administratif. 
Sedangkan pada pasal 30, Anggota DPRD mempunyai kewajiban, yaitu :

a. Memegang teguh dan mengamalkan Pancasila;

b. Melaksanakan Undang-Undang Dasar Negara Republik Indonesia Tahun 1945 dan menaati peraturan perundang-undangan;

c. Mempertahankan dan memelihara kerukunan nasional dan keutuhan Negara Kesatuan Republik Indonesia;

d. Mendahulukan kepentingan Negara di atas kepentingan pribadi, kelompok, dan golongan;

e. Memperjuangkan peningkatan kesejahteraan rakyat;

f. Menaati prinsip demokrasi dalam penyelenggaraan pemerintahan daerah;

g. Menaati tata tertib dan kode etik;

h. Menjaga etika dan norma dalam hubungan kerja dengan lembaga lain dalam penyelenggaraan pemerintah daerah;

i. $\quad$ Menyerap dan menghimpun aspirasi konstituen melalui kunjungan kerja secara berkala;

j. $\quad$ Menampung dan menindaklanjuti aspirasi dan pengaduan masyarakat; dan

k. Memberikan pertanggungjawaban secara moral dan politis kepada konstituen di daerah pemilihannya.

\section{Pemahaman Anggota DPRD Mengenai Fungsi Dewan dan Penerapannya}

Sebagaimana tertuang dalam Peraturan DPRD Kota Batu Nomor 01 Tahun 2010 pasal 4 ayat 1, menyebutkan bahwa DPRD mempunyai 3 (tiga) fungsi. Tiga fungsi tersebut yaitu fungsi legislasi, anggaran, dan pengawasan. Ketiganya dijabarkan pada ayat 2, yaitu fungsi legislasi diwujudkan dalam membentuk Peraturan Daerah (PERDA) bersama Kepala Daerah; ayat 3, yaitu fungsi anggaran diwujudkan daam membahas dan menyetujui Rancangan Anggaran Pendapatan dan Belanja Daerah (RAPBD) bersama Kepala Daerah; dan ayat 4, yaitu fungsi pengawasan diwujudkan dalam bentuk pengawasan terhadap pelaksanaan Undang-Undang, Peraturan Daerah, Peraturan Kepala Daerah, APBD dan Kebijakan yang ditetapkan oleh Pemerintah Daerah. Dimana ketiga fungsi itu dijalankan dalam kerangkan representasi rakyat di daerah seperti yang tertulis pada ayat 5 tentang Tugas dan Wewenang DPRD.

\section{Fungsi Legislasi}

Seperti yang telah dijelaskan sebelumnya bahwa fungsi legislasi diwujudkan dalam membentuk Peraturan Daerah (PERDA) bersama Kepala Daerah. DPRD Kota Batu bersamasama Pemerintah Daerah Kota Batu telah melaksanakan fungsi legislasinya dalam hal pembuatan Peraturan Daerah (PERDA). PERDA yang telah diproduksi oleh pemerintah daerah dalam hal ini pihak eksekutif Kota Batu mencapai 14 Perda, dimana 13 PERDA tentang Pajak dan Retribusi, sedangkan 1 (satu) PERDA lagi mengenai merupakan 100 desa menjadi kelurahan. Sementara itu, PERDA yang akan diproduksi oleh anggota dewan (DPRD) saat ini hanya satu PERDA, yaitu PERDA Inisiatif yang belum dibahas.

Berdasarkan Peraturan Daerah (PERDA) yang telah ditetapkan oleh anggota Dewan, dalam hal ini DPRD Kota Batu, dimana dari keseluruhan Peraturan Daerah yang berhasil 
ditetapkan oleh DPRD tersebut, tidak ada satu Peraturan Daerah pun yang merupakan PERDA inisiatif dari Dewan. Jadi pelaksanaannya ternyata partisipasi aktif Dewan baru terbatas pada proses pembahasan dan memberikan persetujuan terhadap usulan rancangan yang diajukan oleh pihak Eksekutif. Terlihat bahwa penggunaan hak inisiatif oleh DPRD dalam melakukan fungsi legislasinya belum berjalan sebagaimana mestinya, karena RAPERDA yang dijadikan PERDA semuanya berasal dari Pemerintah Daerah Kota Batu. Jadi dapat dikatakan bahwa peran DPRD terhadap keberadaan produk legislasi rendah sekali dibanding dengan peran Pemerintah Kota Batu. Keadaan demikian menunjukkan bahwa lembaga legislatif belum memperlihatkan prakarsanya yang maksimal dalam menampung aspirasi masyarakat dalam rangka perwujudan demokrasi yang diwakilkan oleh rakyat kepada mereka. Kesan DPRD sebagai badan yang hanya melegitimasi usulan/rancangan yang berasal dari Pemerintah Kota Batu, akan hilang apabila DPRD lebih banyak menggunakan hak inisiatifnya.

\section{Fungsi Anggaran}

Fungsi anggaran diwujudkan dalam membahas dan menyetujui RAPBD bersama Kepala Daerah. DPRD Kota Batu bersama-sama Pemerintah Daerah Kota Batu telah melaksanakan fungsi anggarannya dalam hal membahas dan menyetujui RAPBD. RAPBD Kota Batu tahun 2010 yang telah disetujui menjadi APBD oleh anggota dewan (DPRD) mencapai Rp. 416.385.466.953,43 dalam satu tahun. Dimana APBD bersumber dari Pendapatan Asli Daerah (PAD), Dana Berimbang Daerah, DAK dan DAU.

Dalam pembahasan RAPBD dan Penyetujuan RAPBD Kota Batu antara Pemerintah Daerah dan DPRD Kota Batu, tidak ditemukan kendala yang signifikan kalau kedua belah pihak saling memahami kepentingan masing-masing (sharing-profit) sehingga proses pembahasan dan penetapan RAPBD menjadi APBD berlangsung lancar. Apabila kepentingan masing-masing belum ada titik terang maka pembahasan dan penetapan RAPBD menjadi APBD akan berlangsung lama. Sebagaimana yang hasil wawancara oleh oleh peneliti kepada staf Sekretariat DPRD Kota Batu, yang menyatakan bahwa:

"Pembahasan dan penetapan RAPBD Pemerintah Kota Batu yang nantinya akan menjadi APBD Kota Batu oleh DPRD dan Pemerintah Kota Batu tidak mengalami kendala yang berarti kalau sudah ketemu kepentingan masing-masing atau sudah dil-dilan diantara keduanya dan bersifat tradisionil”. (Oktober 2010)

Tingginya APBD Kota Batu yang telah ditetapkan oleh DPRD Kota Batu bersama Pemerintah Kota Batu, belum memberikan dampak perubahan yang besar kepada kesejahteraan masyarakat yang nota bene sebagai konstituen dan obyek dalam pembagunan daerah. Masyarakat cenderung terbebani terhadap kebijakan pemerintah, seperti yang terjadi di Pasar Besar Kota Batu. Dimana sebagian masyarakat mengeluh dengan kebijakan pemerintah yang jauh dari mensejahterakan masyarakat.

\section{Fungsi Pengawasan}

Sementara itu, fungsi pengawasan diwujudkan dalam bentuk pengawasan terhadap pelaksanaan Undang-Undang, Peraturan Daerah, Peraturan Kepala Daerah, APBD dan 
Kebijakan yang ditetapkan oleh Pemerintah Daerah. Fungsi pengawasan menjadi titik krusial penciptaan pemerintahan yang baik (good governance), karena akan mempersempit ruang bagi terjadinya perbuatan pemerintah yang tercela. Perbuatan pemerintah yang tercela frekuensinya lebih banyak terjadi dalam pemerintahan yang bebas, sedangkan pemerintahan yang bebas identik dengan penerapan otonomi daerah, dimana pemberian kewenangan dan keleluasaan diberikan kepada daerah untuk mengelola dan memanfaatkan sumber daya daerah secara optimal bagi kesejahteraan masyarakat.

Peran DPRD dalam melakukan fungsi pengawasan ini sangat penting untuk mencegah terjadinya penyalagunaan, penyelewengan dan kebocoran yang dilakukan oleh pihak eksekutif dalam penyelenggaraan pemerintahan di daerah. Dalam melaksanakan fungsi pengawasan ini, DPRD sebenarnya mempunyai fungsi yang luas untuk dapat melaksanakannya, sebagaimana diatur dalam Undang-undang Nomor 32 Tahun 2009. Meskipun demikian, dalam prakteknya fungsi pengawasan tersebut belum berjalan secara efektif.

Hal ini dapat dilihat antara lain dari keluaran kebijakan di daerah yang lebih mencerminkan produk pemerintah daripada realisasi keinginan rakyat melalui badan perwakilannya, sementara persetujuan rakyat melalui DPRD lebih untuk memenuhi tata cara politik semata. Dari segi kelembagaan, sering dirasakan oleh sementara masyarakat seolah-olah legislatif belum begitu berperan dalam melakukan fungsi kontrol popular yang dimilikinya, yakni pengawasan masyarakat terhadap pemerintah. Pengawasan sosial nampaknya belum dapat terlaksana sebagaimana diharapkan. Hal tersebut antara lain karena wadah penyalur aspirasi/keinginan rakyat yang juga merupakan salah satu fungsi kontrol belum berfungsi dengan baik. Pengawasan sosial melalui lembaga legislatif juga masih lemah, terbukti dengan masih banyaknya kritik masyarakat yang ditujukan kepada DPRD, baik yang dilontarkan secara langsung maupun melalui media massa, yang menyatakan bahwa DPRD belum dapat berbuat banyak dalam menampung seta menyalurkan aspirasi masyarakat.

Dalam rangka memahami fungsi dewan dan penerapannya, latar belakang masing-masing anggota dewan mempunyai peranan penting. Salah satunya latar belakang pendidikan. Tujuan pendidikan adalah menjawab tantangan sosial, ekonomi dan keadilan. Dalam perpektif ini pendididkan diarahkan menyiapkan orang untuk bisa mengenali dan menjelaskan masalah-masalah yang mengahasilkan jawaban-jawaban yang mendasar pada etika. Pada hakikatnya pendidikan adalah pelibatan politik. Dalam konteks ini peserta didik diarahkan untuk berkembang menjadi warga Negara yang dimiliki komitmen pada nilai-nilai demokratis, yakni mampu dan berpartisipasi dalam proses sosial, politik dan ekonomi. Oleh karena itu perolehan pengetahuan dan keterampilan bukan untuk kepentingan dirinya sendiri dan bukan demi ilmu pengetahuan itu sendiri tetapi pelayanan dan kesejahteraan masyarakat.

\section{Evaluasi Kinerja Bidang Penganggaran}

Evaluasi kinerja bidang anggaran yang sudah dilakukan oleh anggota DPRD dengan memanfaatkan Alat Kelengkapan Dewan yang terkait dalam menjalankan fungsi anggarannya sudah berjalan cukup optimal, artinya bahwa anggota dewan DPRD Kota Batu bersama-sama Pemerintah Daerah Kota Batu telah melaksanakan fungsi anggarannya dalam hal membahas 
dan menyetujui RAPBD. Dalam pembahasan RAPBD dan Penyetujuan RAPBD Kota Batu antara Pemerintah Daerah dan DPRD Kota Batu, tidak ditemukan kendala yang signifikan kalau kedua belah pihak saling memahami kepentingan masing-masing (sharing-profit) sehingga proses pembahasan dan penetapan RAPBD menjadi APBD berlangsung lancar. Sebagaimana yang hasil wawancara oleh peneliti kepada staf Sekretariat DPRD Kota Batu, yang menyatakan bahwa:

"Pembahasan dan penetapan RAPBD Pemerintah Kota Batu yang nantinya akan menjadi APBD Kota Batu oleh DPRD dan Pemerintah Kota Batu tidak mengalami kendala yang berarti”. (Oktober 2010)

Hal ini jika dikaitkan dengan pemahaman anggota dewan tentang fungsi penganggaran bahwa sebenarnya anggota dewan sudah menjalankan fungsi anggarannya secara efektif karena seringkali tidak mengalami kendala yang begitu berarti. Masalah penggaran ini sangat perlu dicermati karena dapat dijadikan penilaian terhadap pemerintah mengenai keberpihakan terhadap masyarakat lemah dan dapat mempengaruhi kebijakan yang nantinya akan diterapkan pada suatu daerah baik pada bidang perencanaan dan penganggaran maupun dalam bidang partisipasi masyarakatnya. Dimana dalam peraturan baru bahwa persoalan partisipasi masyarakat dalam perencanaan dan penganggaran melibatkan berbagai stakeholder baik dari DPRD, Pemerintah Daerah, Masyarakat,maupun organisasi non-pemerintah.

Akan tetapi, dalam proses tawar menawar dalam penentuan besarnya anggaran, seringkali anggota dewan masih menggunakan proses dil-dilan, hal ini sesuai dengan hasil wawancara oleh peneliti kepada staf Sekretariatan DPRD Kota Batu, yang menyatakan bahwa:

"Pembahasan dan penetapan RAPBD Pemerintah Kota Batu yang nantinya akan menjadi APBD Kota Batu oleh DPRD dan Pemerintah Kota Batu tidak mengalami kendala yang berarti kalau sudah ketemu kepentingan masing-masing atau sudah dil-dilan diantara keduanya dan bersifat tradisionil”. (Oktober 2010)

Sistem penganggaran dilakukan secara tradisionil yang dimaksud adalah bahwa tiap tahun program yang dilakukan sama dengan tahun sebelumnya, misal anggaran sekretariatan tiap tahun anggaran sebesar 800 juta padahal tidak ada aturan tertulis. Jika diikaitkan kembali dengan pemahaman anggota dewan tentang fungsi anggaran kenapa dalam proses penentuan penganggaran masih ada proses tawar menawar, ketika hal ini dikonfirmasi ternyata tiap pembahasan APBD antara Eksekutif dan Legislatif dapat dikondisikan asal semua kepentingan terpenuhi, artinya ada dil-dilan pada penetapan APBD antara anggota dewan dengan pemerintah. Selain itu juga seringkali dana anggota dewan lebih dari pagu yang ditetapkan oleh Pemkot Batu namun tetap disetujui karena takut anggaran Pemkot tidak di "dok" oleh anggota dewan sehingga merugikan Pemkot batu. Hal tersebut perlu dievaluasi kembali tentang pemahaman anggota dewan terkait dengan fungsi penganggaran, menginggat masalah penganggaran akan dijadikan penilaian oleh pemerintah dalam membuat kebjakan yang akan berimpilkasi terhadap kesejahteraan masyarakat. 


\section{E. KESIMPULAN DAN REKOMENDASI}

\section{Kesimpulan}

1. Pemahaman anggota DPRD Kota Batu dan penerapannya terhadap ketiga fungsi utama, yaitu legislasi, penganggaran dan pengawasan. Fungsi legislasi, DPRD Kota Batu sejauh ini masih melegitimasi PERDA yang diusulkan oleh Pemerintah Kota Batu. Fungsi penganggaran, DPRD Kota Batu sejauh ini masih membahas dan metenapkan RAPBD menjadi APBD dari Pemerintah Kota Batu. Fungsi pengawasan, DPRD Kota Batu cukup responsif terhadap respon dari masyarakat, tapi perlu diperkuat lagi bersama masyarakat dalam mengawasi kebijakan Pemerintah Kota Batu.

2. Evaluasi kinerja anggaran oleh angota dewan DPRD telah memanfaatkan Alat Kelengkapan Dewan yang terkait dengan penganggaran yaitu Badan Anggaran, akan tetapi seringkali dana anggota dewan lebih dari pagu yang ditetapkan oleh Pemkot Batu namun tetap disetujui karena takut anggaran Pemkot tidak di "dok" oleh anggota dewan sehingga merugikan Pemkot batu.

\section{Rekomendasi}

Optimalisasi alat kelengkapan dewan, di samping untuk membantu atau memberi masukan kepada anggota dewan juga untuk meningkatkan pemahaman mengenai substansi proses dan fungsi anggaran daerah sehingga berimplikasi kepada kesejahteraan masyarakat. Selain itu juga itu dibutuhkan kesadaran yang mendalam anggota DPRD Kota Batu dalam memahami dan merealisasikan fungsinya sebagai anggota dewan yang merupakan representasi dari masyarakat Kota Batu.

\section{DAFTAR PUSTAKA}

Bungin, Burhin. 2007. Penelitian Kualitatif. Jakarta: Kencana Prenada Media Group

Himawan E. B. 2010. Pembentukan Peraturan Daerah. www.google.com. Diakses 19 april 2010, 8:10AM

Keputusan Presiden Nomor 80 Tahun 2003 Tentang Pedoman Pelaksanaan Pengadaan Barang/ Jasa Instansi Pemerintah pasal 3

Ketetapan Majelis Permusyawaratan Rakyat Republik Indonesia Nomor III/MPR/2000 Tentang Sumber Hukum Dan Tata Urutan Peraturan Perundang-Undangan

Mason, J. 1996. Qualitatif Researching. Sage. London. Hal 4

Moleong, Prof. DR. Lexy J. 2008. Metodologi Penelitian Kualitatif. Cetakan Kedua puluh lima. PT Remaja Rosdakarya. Bandung. 
Muhammad D, 2008, Semarang, Anteseden dan Konsekuensi Partisipasi Penganggaran(Studi Empiris pada Satuan Kerja Perangkat Daerah Pemerintah Daerah Kota Palu), Tesis, Program Studi Magister Sains Akuntansi Program Pascasarjana Universitas Diponegoro, Semarang Peraturan Presiden Republik Indonesia Nomor 61 Tahun 2005 Tentang Tata Cara Penyusunan dan Pengelolaan Program Legislasi Nasional

Peraturan Menteri Dalam Negeri Nomor 13 Tahun 2010 Tentang Pedoman Pelaksanaan Fungsi Pengawasan Dewan Perwakilan Rakyat Daerah Terhadap Tindak Lanjut Hasil Pemeriksaan Badan Pemeriksa Keuangan

Peraturan Pemerintah Republik Indonesia Nomor 16 Tahun 2000 Tentang Pengelolaan dan Pertanggungjawaban Keuangan Dalam Pelaksanaan Dekonsentrasi dan Tugas Pembantuan

Pietra W, Penganggaran Daerah. http://google.co.id. Diakses 18 April 2010, 10.20 PM

Sugiyono. 2007. Memahami Penelitian Kualitatif. Bandung: ALFABETA.

Undang-Undang Republik Indonesia Nomor 22 Tahun 2003 Tentang Susunan Dan Kedudukan Majelis Permusyawaratan Rakyat, Dewan Perwakilan Rakyat, Dewan Perwakilan Daerah, Dan Dewan Perwakilan Rakyat Daerah

Undang Undang RI No. 33/Tahun 2004 tentang Perimbangan Keuangan Antara Pemerintah Pusat dan Pemerintah Daerah.

Undang-Undang Republik Indonesia Nomor 27 Tahun 2009 Tentang Majelis Permusyawaratan Rakyat, Dewan Perwakilan Rakyat, Dewan Perwakilan Daerah, Dan Dewan Perwakilan Rakyat Daerah

Undang-Undang Republik Indonesia Nomor 10 Tahun 2004 Tentang Pembentukan Peraturan Perundang-Undangan

Wahyu D W, 2007, Semarang, Tugas Akhir, Kajian Partisipasi Masyarakat Dalam Perencanaan Dan Penganggaran Pembangunan Daerah Di Kabupaten Pati. Jurusan Perencanaan Wilayah Dan Kota Fakultas Teknik Universitas Diponegoro, Semarang

Wismar E, 2004, Yogyakarta, Analisis Peranan Badan Legislatif Daerah Dalam Pembentukan Perda (Studi di DPRD Kota Yogyakarta), Tesis, Magister Administrasi Publik Universitas Gadjah Mada Yogyakarta

Yusak E B, 2004, Yogyakarta, Pelaksanaan Fungsi Pengawasan Oleh DPRD dalam Rangka Mewujudkan Pemerintahan yang Baik di Kabupaten Timor Tengah Selatan, Tesis, Program Studi Magister Hukum Program Pasca Sarjana Magister Hukum Universitas Gadjah Mada, Yogyakarta

www.parlemen.net, 2010. Pusat Studi Hukum \& Kebijakan Indonesia 